\title{
Medallas de la Gran Logia Nacional de España, 1809- 1812 (Análisis documental e iconográfico)
}

\author{
Medals of National Grand Lodge of Spain, 1809-1812 \\ (Documentary and iconographic analysis)
}

\author{
Manuel Cuadrado Merchán \\ Universidad de Las Palmas de Gran Canaria, España \\ manuelcuadrado@joyeriagrancanaria.com \\ María de los Reyes Hernández Socorro \\ Universidad de Las Palmas de Gran Canaria, España \\ $\underline{\text { mariadelosreyes.hernandez@ulpgc.es }}$ \\ Santiago de Luxán Meléndez \\ Universidad de Las Palmas de Gran Canaria, España \\ sluxan@dch.ulpgc.es
}

Recepción: 19 de noviembre de 2018/Aceptación: 15 de diciembre de 2018.

doi: https://doi.org/10.15517/rehmlac.v10i2.35234

Palabras clave

masonería española; 1809-1812; medalla; orfebre; fuentes documentales.

Keywords:

Spanish freemasonry; 1809-1812; medal; goldsmith; documentary sources.

Resumen

Las medallas de la masonería española, como signo de identidad, soporte expresivo y vehículo de comunicación forman un conjunto singular. El estudio de las medallas masónicas españolas está por aún hacerse a diferencia de otros países como el Reino Unido o Francia. Cabe preguntarse si el hecho de que la masonería española haya pasado por largos periodos de prohibición y sus miembros hayan sido criminalizados, son un factor determinante para encontrarnos con este vacío. Las primeras medallas masónicas españolas de las que hay constancia corresponden a los talleres adscritos a la Gran Logia Nacional de España, obediencia que estuvo activa durante el reinado de José I. A través de distintas fuentes documentales, podemos hacer una relación y estudio de aquellas medallas, así como abrir una ventana desde la cual asomarnos a los inicios del arte masónico español para conocer la autoría, vicisitudes y personalidad de alguno de sus protagonistas.

Abstract

The medals of Spanish Freemasonry, as a sign of identity, expressive frame and communication vehicle, form a unique ensemble in the Masonic art scene. Unlike in other countries such as the United Kingdom and France, the study of Spanish Masonic medals has yet to be completed. One might therefore wonder whether the fact 
that Spanish Freemasonry had prolonged periods of prohibition and its members were criminalized is a major factor in explaining this gap. The first Spanish documented medals correspond to the lodges attached to The Grand National Lodge of Spain, obedience that was active during the reign of Joseph I. Through different documentary sources, those medals can be reported and studied, as well as open a new window to look out to the beginnings of Spanish Masonic art in order to know the authorship, the vicissitudes and the character of some of its protagonists.

\section{Introducción}

El presente artículo forma parte del trabajo de investigación que se inscribe dentro de las actividades del programa de doctorado "Islas atlánticas: historia, patrimonio y marco jurídico institucional", de la Universidad de Las Palmas de Gran Canaria.

En "estado del arte" hemos comenzado haciendo referencia al trabajo del profesor Ferrer Benimeli, señalando la importancia de sus trabajos y actividades para impulsar la renovación de los estudios masónicos desde el último cuarto del siglo XX hasta la actualidad. Actividad ésta a la que han contribuido otros muchos investigadores vinculados a la docencia, así como especialistas de diversos ámbitos -entre los que se encuentran la archivística o el derecho-. A continuación, con el objetivo de contextualizar nuestro trabajo, hemos creído oportuno describir las categorías que pertenecen al espacio de estudio de la numismática en el ámbito de las artes, para seguidamente presentar una relación de publicaciones que dan cuenta de las investigaciones sobre arte masónico debidas a especialistas en esta disciplina. Incluimos también en este apartado unas consideraciones sobre coleccionismo y mercado de arte masónico en España. Para finalizar hacemos unas observaciones sobre el patrimonio artístico masónico y su ausencia en los manuales de historia del arte.

Con el título "La Gran Logia Nacional de España" abordamos el capítulo en el cual describimos la idiosincrasia de la institución y el perfil sociológico e ideología política de sus miembros, además de los actores que intervienen en la producción de estas singulares piezas numismáticas.

El marco territorial focalizado en Madrid y el periodo que discurre entre la entronización y la caída del rey José I -con el trasfondo de la Guerra de Independencia-, configuran un conjunto escénico que nos permite comprender el contexto en el que se desarrolla la producción de estas medallas.

En los epígrafes siguientes hemos analizado y explicado la iconografía y el simbolismo de cada una de las medallas, con el objetivo de desvelar el mensaje que transmiten aquellas piezas, ya sea a través de las imágenes disponibles como a partir de las descripciones. Asimismo, nos hemos encontrado con la necesidad de investigar la intencionalidad, la función atribuida en el seno de una organización masónica y las circunstancias que motivaron su acuñación. 
Un capítulo lo hemos dedicado a la biografía de Vicente Goldon y Bibiani. La investigación historiográfica realizada sobre la figura de este joyero, masón y afrancesado nos ha permitido conocer aspectos de la vida y obra de un personaje que ejemplifica los avatares en los que se vieron inmersos otros que, como él, formaron parte de ese señalado grupo social.

Finalmente, en las "Conclusiones" damos cuenta del significado y alcance que para la historia del arte y la masonología españolas puede significar lo expuesto en el presente trabajo.

El método para abordar el estudio sobre este conjunto de cinco medallas necesariamente tenía que hacerse conforme a un modelo de catalogación numismático ${ }^{1}$. Ahora bien, las singulares circunstancias que concurren condicionan el esquema descriptivo de las dos piezas más importantes, pues aún disponiendo de imágenes y referencias catalográficas a través de fuentes secundarias, no hemos podido acceder a la fuente primaria. Esto, en la práctica, significa que no se han podido analizar en un laboratorio y obtener datos metrológicos fisicoquímicos. Por este motivo hemos decidido aplicar un esquema iconográfico. Las otras tres medallas las hemos catalogado apoyándonos en las descripciones que aparecen en las fuentes documentales habida cuenta de que no hay constancia de ellas en catálogo alguno.

Para documentarnos hemos recurrido a fuentes primarias obtenidas de distintos archivos: Nobleza de Toledo, Diocesano de Madrid, Centro Documental de la Memoria Histórica (CDMH) o Histórico Nacional. Para las referencias a documentos del Archivo de Palacio nos hemos apoyado en fuentes secundarias. También hemos acudido a los fondos documentales digitalizados de hemerotecas y bibliotecas nacionales y extranjeras, así como a los repositorios, bases de datos digitales y revistas electrónicas cuya consulta puede realizarse por internet. Del mismo modo, una parte de la bibliografía la hemos consultado en bibliotecas públicas y de particulares.

\section{Estado del arte}

El profesor Ferrer Benimeli publicó en 1974 una Bibliografía de la masonería que, en ediciones posteriores, ha ido ampliando ${ }^{2}$. En este sentido, ya en la comunicación con el mismo título que presentó en el Symposium de Metodología Aplicada a la Historia de la

\footnotetext{
${ }^{1}$ María del Mar Royo Martínez, "Guía de descripción, estudio y clasificación de monedas para numismática", Reduca 5, no. 1 (2013), 64-115, http://www.revistareduca.es/index.php/reduca/article/view/1585/1606

${ }^{2}$ José Antonio Ferrer Benimeli y Bird Polly, Bibliografia de la masonería (Madrid: Fundación Universitaria Española, 2004).
} 
Masonería Española, celebrado en Zaragoza en $1983^{3}$, indicaba los criterios diferenciadores que convenía tener presentes a la hora de consultar fuentes bibliográficas relativas a la masonería, a la vez que las clasificaba conforme a un cuadro sinóptico. La figura del profesor Ferrer Benimeli ha sido fundamental para impulsar el estudio de la masonería española desde criterios estrictamente historiográficos.

Las actividades impulsadas por el Centro de Estudios Históricos de la Masonería Española (CEHME) ${ }^{4}$, del que es fundador, y las ponencias presentadas por los numerosos investigadores y especialistas que han participado en los distintos simposios que el CEHME ha organizado, han servido para que, ya desde hace décadas, generaciones de investigadores aborden estos estudios a partir del rigor del método historiográfico.

Del mismo modo, fruto de esta labor de investigación se han echado por tierra leyendas que han partido de las filas antimasónicas, pero que también las ha alimentado la misma masonería española -aún hoy podemos encontrar textos salidos de la pluma de algunos masones españoles empeñados en alimentar estos mitos- ${ }^{5}$.

Creemos oportuno señalar que el estudio de la medallística masónica española implica analizar una manifestación artística singular, más aún si consideramos que la investigación académica de las diferentes manifestaciones artísticas de la masonería española es un territorio parcialmente explorado.

Llegados a este punto, conviene detenernos para hacer unas precisiones sobre numismática y medallística.

El término medalla hace referencia a un objeto generalmente metálico y sin valor nominal que tiene su origen en la necesidad de cumplir diferentes funciones, desde la decoración artística, conmemorativa y propagandística; las honoríficas y de uso protocolario; hasta aquellas estrictamente funcionales u operativas. Pero también sirven como vehículo distintivo para satisfacer la necesidad de expresar la identidad política, religiosa o pertenencia y estatus en el seno de un determinado grupo social.

La disciplina que se ocupa de su estudio se denomina medallística, entendida como una especialidad de la numismática en tanto que ciencia auxiliar de la historia del arte. No obstante, dentro de la medallística hay otros ámbitos de estudio más específicos. Por un lado, la exonumia, que se ocupa de aquellos objetos que, siendo semejantes a las monedas (monetiformes), carecen de valor de curso legal. En esta clasificación entrarían los jetons,

\footnotetext{
${ }^{3}$ Ferrer Benimeli, "Bibliografía de la masonería", en La masonería en la historia de España: actas del I Symposium de Metodología Aplicada a la Historia de la Masonería Española, coord. Ferrer Benimeli (Zaragoza: Diputación General de Aragón, Departamento de Educación y Cultura, 1983), 371-377.

${ }^{4}$ Centro de Estudios Históricos de la Masonería Española, http://cehme.com/

${ }^{5}$ Galo Sánchez Casado, Los altos grados de la masonería (Madrid: Akal, 2009); Ilia Galán, "Introducción”, Conde de Aranda. Estudios a la luz de la francmasonería 1 (2006): 13-20; o la página http://www.lamatritense.es/ donde, además de recurrir a los tópicos e inexactitudes habituales, en una ilustración se identifica a Philip Wharton cuando en realidad el retratado es Thomas Dunckerley.
} 
tokens o las fichas de valor y uso interno en empresas y asociaciones. Y la falerística, por otro, estudia las condecoraciones institucionales y los derechos asociados a estas distinciones honoríficas.

A continuación, señalamos algunos trabajos de investigación, artículos y publicaciones como marco de referencia para situar nuestro trabajo dentro del espacio artístico de la masonería española.

Sobre la arquitectura masónica, el profesor David Martín López leyó en 2010 su tesis doctora $^{6}$, centrada en esta expresión artística en la que es especialista, como se pone de manifiesto cuando -en distintos trabajos- aborda casos concretos, como la restauración del patrimonio arquitectónico masónico, los espacios y entornos singulares, o la obra de arquitectos de filiación masónica. En otros casos se acerca al binomio arte-masonería desde un enfoque teorético y metodológico ${ }^{7}$.

Por otro lado, abundan las referencias que vinculan arquitectura y masonería desde una perspectiva esotérica ${ }^{8}$ o alegórica $^{9}$, con el propósito de tender puentes entre el simbolismo masónico y la denominada "tradición perenne" en su acepción actual.

También encontramos autores que analizan el vínculo entre cine y masonería ${ }^{10}$, y los que estudian la sigilografía de las logias desde perspectivas etnográficas, cronológicas o geográficas $^{11}$.

Otro grupo de investigadores se han ocupado del análisis sistematizado del corpus iconográfico masónico ${ }^{12}$.

\footnotetext{
${ }^{6}$ David Martín López, "Estética masónica, arquitectura y urbanismo. Siglos XVIII-XX” (Tesis de doctorado en historia del arte y música, Universidad de Granada, 2010).

${ }^{7}$ Martín López, “Arte y masonería: consideraciones metodológicas”, REHMLAC 1, no. 2 (diciembre 2009-abril 2010): 17-36, https://revistas.ucr.ac.cr/index.php/rehmlac/article/view/6615/6304

${ }^{8}$ Josep M. Gracía, Simbólica arquitectónica (Barcelona: Edición del autor, 2004).

${ }^{9}$ Raimon Arola, Simbolismo del templo (Barcelona: Ediciones Obelisco, 2001).

${ }^{10}$ Ricardo Serna Galindo, "La masonería en el séptimo arte. Una aproximación al caso español”, REHMLAC+ 8, no. 1 (mayo-noviembre 2016): 71-86, https://doi.org/10.15517/rehmlac.v8i1

${ }^{11}$ Ver: Consuelo Conde Martel, "Aspectos simbólicos de los sellos masónicos en Canarias y de la logia Añaza", Tebeto: Anuario del Archivo Histórico Insular de Fuerteventura 2 (1989): 129-178; Susana Cuartero Escobés, "Sigilografía de las logias norteamericanas", Brocar: Cuadernos de investigación histórica 17 (1991): 55-70; o María Elena Muñoz Echeverría y María Jesús Ocaña Vázquez, "Elementos indígenas y de ultramar en los sellos de las logias de Cuba y Filipinas", en Masonería española y americana, coord. Ferrer Benimeli (Zaragoza: Gobierno de Aragón, Departamento de Educación, Cultura y Deporte, 1995), tomo II, 1005-1018.

${ }^{12}$ Numerosas publicaciones reflejan la relación entre iconografía y simbolismo masónicos. En: José Julio García Arranz, Simbolismo masónico. Historia, fuentes e iconografía (Vitoria-Gasteiz: Sans Soleil Ediciones, 2017), encontramos uno de los ejemplos que consideramos más exhaustivo y mejor reseñado.
} 
Entre los estudios que abordan pintura y masonería podemos citar los trabajos sobre los pintores Juan Gris ${ }^{13}$, José Aguiar ${ }^{14}$ o Nicomedes Gómez ${ }^{15}$.

Si el número de estudios de investigación y publicaciones especializadas que abordan las expresiones artísticas de la masonería española en relación con las bellas artes podemos decir que es -cuando menos- parco, el panorama de los trabajos realizados sobre las llamadas artes aplicadas en la masonería española es todavía menor. No obstante, hemos hallado alguna referencia sobre cerámica masónica y decoración mural ${ }^{16}$, y otras que estudian ediciones filatélicas ${ }^{17}$ y su relación con la masonería española.

Las fotografías de temática masónica son muy abundantes en el $\mathrm{CDMH}$, y con frecuencia se recurre a estos fondos para ilustrar publicaciones de diferente índole referidos a la Masonería española ${ }^{18}$.

Sobre otras artes aplicadas - como las del vidrio, el libro, la forja o el mobiliarioaparecen algunas citas tangenciales en el contexto de artículos o publicaciones que estudian la historia de la masonería española desde otras perspectivas ${ }^{19}$. Un ejemplo frecuente lo encontramos en las abundantes relaciones de los oficios profanos desempeñados por los miembros de aquellas logias, objeto de investigación en estudios sociológicos, políticos o

\footnotetext{
${ }_{13}$ José A. García-Diego, Antonio Machado y Juan Gris. Dos artistas masones, ed. Castalia (Madrid, 1990); e Íñigo Sarriugarte Gómez, "Perspectivas masónicas en la vida y producción artística de Juan Gris", Cuadernos de arte e iconografia 46 (2014): 523-547.

14 Manuel de Paz-Sánchez, "José Aguiar (1895-1976). Entre la luz y las sombras", Anuario de Estudios Atlánticos 52 (2006): 499-528.

15 Jesús Rodríguez Rubio, "Un ejemplo de arte masónico: Nicomedes Gómez (1903-1983)", en Masonería, revolución y reacción, coord. Ferrer Benimeli (Alicante: CEHME, 1990): tomo II, 897-904.

${ }^{16}$ En I. Echeverría, "La Masonería en la cerámica del ParK Güell”, Conbarro: revista internacional de arte 6 (2004): 34-38, aparece una descripción de elementos iconográficos masónicos del Park Güell de Barcelona representados con las características teselas decorativas de ese espacio.

${ }^{17}$ Consultar: Juan Sabater Pie, "La crisis del 98 en la filatelia masónica", en La masonería española y la crisis colonial del 98, coord. Ferrer Benimeli (Zaragoza: CEHME, 1999), tomo I, 159-175; y también: "La masonería en Madrid desde la filatelia (1728-2003)", en La masonería en Madrid y en España del siglo XVIII al XXI, coord. Ferrer Benimeli (Zaragoza: CEHME, 2004), tomo I, 697-720.

${ }^{18}$ En Sylvia Hottinger Craig, "Las fotografías de mujeres entre las fotografías de origen masónico del archivo general de la Guerra Civil española", en La masonería española: represión y exilios, coord. Ferrer Benimeli (Zaragoza: CEHME, 2011), tomo II, 1417-1430, encontramos un estudio de género sobre fotografía, masonería y mujer; y en María Pilar Amador Carretero, "La fotografía como control policial", en La masonería española: represión y exilios, coord. Ferrer Benimeli (Zaragoza: CEHME, 2011), tomo II, 1391-1416, otro trabajo en el que, además de presentar una relación temática de las fotografías masónicas del CDMH, se aborda la importancia de la fotografía como recurso documental al servicio de la represión policial de la masonería. Ver también: Margarita Hernández, Miguel Ángel Jaramillo y Blanca Desantes. "Documentación fotográfica masónica en el Archivo Histórico Nacional: sección guerra civil”, en La masonería española y la crisis colonial del 98, coord. Ferrer Benimeli. (Zaragoza: CEHME, 1999), tomo I, 141-157; y María del Carmen Amate Martínez, Entre la historia y el mito: La Masonería española a través de la fotografía, Catálogo de exposición (Almería: Instituto de estudios almerienses, 2009).

${ }^{19}$ En Gabriel Songel, "El patrón de diseño del Santo Cáliz de Valencia", Revista de Bellas Artes 13 (2016): 213-234, se estudia un caso particular que relaciona la orfebrería con las marcas de canteros.
} 
geográficos. En las listas aparecen plateros, grabadores, pintores, escultores o sastres, por citar alguno.

Para encontrar ejemplos y referencias a la indumentaria, mandiles y otras manifestaciones de arte mobiliar empleado tanto en el contexto ritualístico -sería el caso de las joyas de los diferentes oficios-, como en la decoración del templo, o cuyo destino sea meramente funcional, es preciso consultar registros en hemerotecas ${ }^{20} \mathrm{o}$ en alguno de los catálogos de exposiciones que se han venido realizando desde la legalización de la masonería en España a comienzos del último cuarto del siglo $\mathrm{XX}^{21}$.

Mención aparte merece la primera clasificación y catalogación realizada de la unidad documental "Colección de iconografía masónica" de los fondos masónicos del conocido como "Archivo Masónico de Salamanca", hoy $\mathrm{CDMH}^{22}$. Dada la importancia del trabajo realizado, se organizó una exposición para sacar a luz pública las piezas inventariadas y dar testimonio del trabajo de catalogación realizado. Parte de aquella experiencia consistió en la publicación de un catálogo en el que aparecen referencias a joyas, medallas y troqueles, collarines y un largo etcétera de objetos masónicos. No deja de sorprender el relato de las protagonistas cuando descubren ocultas 400 piezas en el interior de una columna hueca. Esta circunstancia parece sacada de la leyenda masónica que describe las dos columnas del pórtico del templo masónico y le atribuye a su oquedad una antigua función archivística ${ }^{23}$.

Del mismo modo, de la transcendencia de la empresa acometida, da cuenta la importancia de las personalidades que figuran en la nota de agradecimiento al inicio del catálogo: los profesores e historiadores de la masonería António Henrique de Oliveira Marques, Aldo Mola o Marco Novarino.

Una aproximación al estado en el que se encuentra el estudio del "arte masónico" debe completarse con el análisis del problema terminológico a cerca de la denominación apropiada para referirse al conjunto de manifestaciones o expresiones artísticas ${ }^{24}$ de la

\footnotetext{
${ }^{20}$ En Boletín Oficial del Gran Oriente de España, 15 de mayo de 1873, 12, 1 de julio de 1873, 13 y 15 de julio de 1873,16 , se hace referencia a D. M. A. Ricord, grabador madrileño, dando cuenta de las joyas ritualísticas, sellos y otros enseres masónicos de producción propia puestos a la venta, así como de otros elaborados para distintas logias en particular. También en Emilio J. M. Nogués, "Decreto", Boletín de Procedimientos del Soberano Gran Consejo General Ibérico, 3 de abril de 1892, 16, se comunica el decreto por el cual se crea la medalla conmemorativa de la obediencia. A continuación, figura reproducida y se hace referencia al grabador D. Luciano Ortega, acabados, precios y otros detalles. Esta medalla es una de las que figuran en Herrera Chiesanova, Medallas españolas masónicas, 17.

${ }^{21}$ Puede consultarse: La masonería española, 1728-1939. Catálogo de exposición. Alicante: Instituto de Cultura "Juan Gil-Albert", Diputación Provincial de Alicante, 1989; y también: Masonería universal. Una forma de sociabilidad. "Familia gallega" (1814-1936). Catálogo de exposición. A Coruña: Fundación Ara Solis, 1996. ${ }^{22}$ Blanca Desantes y María José Frades, Atributos masónicos en el Archivo Histórico Nacional, Sección Guerra Civil (Salamanca: Dirección General de Bellas Artes y Archivos, 1993).

${ }^{23}$ En "Explicación del Tablero de Trazo de Segundo Grado" del Rito de Emulación.

${ }^{24}$ Muñoz Echeverría y Ocaña Vázquez, “Aproximación a la iconografía y simbología masónica”, en Masonería, revolución y reacción. coord. Ferrer Benimeli (Alicante: CEHME, 1990), tomo II, 885-895. Martín López,
} 
masonería. Seguidamente nos aproximaremos al panorama en el que se encuentra el estudio de las medallas de la masonería española.

Hemos encontrado dos publicaciones que constituyen las primeras -si no las únicasreferencias de la medallística masónica española. Sorprende el intervalo de tiempo transcurrido entre ambas publicaciones, nada menos que 87 años.

La obra titulada Medallas Españolas Masónicas ${ }^{25}$, editada por el historiador y arqueólogo Adolfo Herrera Chiesanova en 1905, representa la primera publicación española de un conjunto de medallas masónicas conforme a criterios propiamente numismáticos. En este catálogo figuran los calcos en relieve y las correspondientes descripciones de 30 medallas. Las piezas, más allá del título del catálogo, proceden de diferentes países latinoamericanos y algunas pertenecen a logias de obediencias españolas: Argentina (1), Costa Rica (1), Cuba (6), México (2), y España (12). Tres de ellas no son masónicas, dos lo son, pero no figura la procedencia, y otra más es de dudosa adscripción masónica. También incluye una francesa y otra portuguesa.

Si bien la obra contiene imprecisiones, errores de atribución y representa un conjunto heterogéneo tanto por la procedencia como por la cronología de las piezas catalogadas, no por ello carece de valor documental e interés para el investigador. Tal es así que, entre las medallas, encontramos la perteneciente a la logia adscrita a la Gran Logia Nacional de España (GLNE), "Napoleón el Grande" de 1811, y sobre la que volveremos más adelante. También proporciona interesante información en torno a otras medallas de las cuales no se conservan ejemplares o carecemos de más registros documentales.

La segunda publicación a la que hacíamos referencia antes corresponde al ya citado Atributos masónicos en el Archivo Histórico Nacional, Sección Guerra Civil publicado en 1993. En ella aparecen reseñadas un gran número de joyas de oficios y de grados, pero también figuran medallas y troqueles de acero para estampar medallas.

Hoy en día los fondos del CDMH, en lo que a medallas se refiere, está completamente informatizado. Y, además, buena parte de las piezas se encuentran fotografiadas y digitalizadas, lo que facilita la consulta en línea de las descripciones e imágenes a través del Portal de Archivos Españoles "PARES"26.

Como también señalamos anteriormente, en los catálogos de las exposiciones sobre masonería que se han celebrado desde su legalización en 1979 se pueden hallar fotografías y reseñas de medallas masónicas pertenecientes tanto a los fondos del CDMH como a colecciones particulares.

\footnotetext{
"Arte y masonería: consideraciones metodológicas"; y también Edgar Ortiz Arellano, "Tendencias artísticas del simbolismo francmasónico", Xihmai Revista 22 (2016): 111-130.

${ }^{25}$ Adolfo Herrera Chiesanova, Medallas españolas masónica (Madrid: Edición del autor, 1905).

${ }^{26}$ Portal PARES de la red de archivos españoles: http://www.pares.mcu.es
} 
Finalmente, y como anécdota, podemos citar el libro Joyas Masónicas ${ }^{27}$, publicado en 1992, y que, contrariamente a lo que podría suponerse por el título, no es un catálogo de joyería masónica. En él se tratan contenidos masónicos relativos a la organización, ritos, o simbolismo, si bien, a modo de ilustración, aparecen fotografías de medallas masónicas, principalmente extranjeras, pero también alguna española contemporánea, como la perteneciente a la logia La Matritense $\mathrm{n}^{\circ} 7$.

A la vista de la escasez de publicaciones sobre las medallas de la masonería española, el investigador que se acerca a esta singular expresión artística no puede menos que constatar que este particular ámbito de estudio es una de las asignaturas pendientes de la masonología española. A diferencia de lo que ocurre en el Reino Unido, Francia, Argentina o Uruguay países "de larga tradición masónica", como se acostumbra a decir-, la producción medallística masónica española no ha sido objeto de investigación salvo por las reseñas citadas.

De entre las distintas hipótesis que pueden barajarse para encontrar una explicación a este hecho, la que presenta mayor verosimilitud es aquella que lo atribuye a los largos periodos de la historia de España en los cuales la masonería ha estado prohibida. Este planteamiento cobra sentido a la luz del escaso número de medallas que se han conservado desde el siglo XIX. Por demás, el razonamiento se explica si consideramos que la condena de la masonería por la Iglesia católica y de la monarquía ha sido una constante desde la publicación de la primera bula In eminenti el 2 de abril de 1738; que las censuras dictadas durante los pontificados siguientes se incorporaron a la legislación penal española particularmente durante el reinado de Fernando VII-; o el ensañamiento con que se persiguió y condenó a los masones desde el inicio de la guerra civil hasta el final de la dictadura franquista. De este modo, no es aventurado considerar que los mismos masones se pudieron deshacer de sus medallas y cualesquiera otros efectos que, de ser hallados en su poder, les supusiera ser acusados de pertenencia a la masonería y, en consecuencia, condenados a largas penas de prisión y depuración administrativa, abocados al destierro o asesinados sin mediar juicio alguno ${ }^{28}$.

Al hilo de este planteamiento, cabe preguntarse si ha existido una tradición de coleccionismo privado de medallas masónicas y, del mismo modo, sobre la existencia de un mercado y una industria interna que satisficiera la demanda nacional de este tipo de medallas, como ocurre en el caso de Francia con la Casa Gloton o la firma Lehmann, o en Reino Unido con las empresas Toye, Kenning, Spencer o Fattorini. Sobre coleccionismo numismático masónico, interesa investigar si las piezas del catálogo de Herrera Chiesanova tienen un

\footnotetext{
${ }^{27}$ Miguel Arias y Alfonso D. Jiménez, Joyas masónicas (Madrid: Iberediciones, 1992).

${ }^{28}$ Severiano Delgado Cruz y Javier Infante Miguel-Motta, "Nadie preguntaba por ellos. Guerra y represión en Salamanca", en Testimonio de voces olvidadas, coord. Enrique Berzal de la Rosa (León: Fundación veintisiete de marzo, 2007), Tomo I, 283-355.
} 
origen común o si procedían de distintas colecciones. Es también el caso de la supuesta medalla masónica de Fray Andrés del Corral $^{29}$, que nos habla tanto de su condición de coleccionista, como de su célebre monetario.

Conviene dar respuesta a estos interrogantes, si bien los resultados de esa investigación exceden los límites del presente artículo.

Si antes describimos la eclosión de los estudios masónicos en el panorama historiográfico español coincidiendo con la transición democrática, creemos conveniente señalar que tanto el patrimonio histórico como la producción artística masónica española aún no aparecen en los índices de las historias generales del arte. Sin embargo, desde otras disciplinas -como la sociología o la filosofía- pensadores y docentes ya se han acercado al estudio de la realidad masónica de este siglo $\mathrm{XXI}^{30}$.

\section{La Gran Logia Nacional de España}

La masonería española, entendida como aquella institución —habitualmente conocida por el término «obediencia»— que aglutina a distintas logias y se autotitula como entidad masónica soberana en una demarcación territorial, nació en 1809 del impulso de la logia de San José (en honor del Rey José I), bajo la denominación de Gran Logia Nacional de España (GLNE). En ella se integraron la logia Beneficencia de Josefina junto a la Santa Julia, Estrella de Napoleón, Los Filadelfos, Edad de Oro o Napoleón el Grande, estando activa entre octubre-noviembre de 1809 y agosto de 1812.

La GLNE ${ }^{31}$ ha sido la primera obediencia masónica constituida en suelo español. Esto significa que, por primera vez en su historia, la masonería fue una organización legal y sus miembros no se vieron perseguidos, pudiendo reunirse con total libertad, a diferencia de lo que ocurría en el pasado como ya hemos apuntado. La GLNE representó una masonería profundamente francófila, estrechamente vinculada con la administración de José I, pero no por ello se puede calificar de antiespañola.

Tradicionalmente se ha calificado a estos masones - y por extensión, a esta primera masonería-, como traidores y colaboracionistas, en tanto que actuaron en complicidad con el «gobierno intruso». Los ejemplos de publicaciones y artículos de prensa posteriores a la

\footnotetext{
${ }^{29}$ Andrés del Corral, El misterio de la iniquidad revelado o el triunfo soñado de la impiedad (Valladolid: Hermanos Santander, 1814).

${ }^{30}$ Monserrat Guibernau, Identidad. Pertenencia, solidaridad y libertad en las sociedades modernas (Madrid: Trotta, 2017); o Javier Otaola y Andrés Ortiz-Osés, Masonéria y hermenéutica. Un mundo problemático (Oviedo: EntreAcacias, 2017).

${ }^{31}$ En Ferrer Benimeli, “4. La primera Gran Logia Nacional de España”, en Masonería española contemporánea Vol.1. 1800-1868 (Madrid, ed. Siglo XXI de España Editores, 1987), 82-105, se hace referencia a las circunstancias que concurrieron hasta la fundación de la GLNE, así como a información sobre las logias que se integraron en la obediencia, personajes y otras referencias.
} 
caída del régimen son numerosos, sobre todo desde las filas de los partidarios del absolutismo borbónico y de la Iglesia católica ${ }^{32}$. La historiografía finisecular decimonónica, de la cual la figura de Marcelino Menéndez Pelayo ${ }^{33}$ fue uno de los principales representantes, también contribuyó a identificar masón con afrancesado y a calificarlos como traidores.

Es evidente el vínculo entre la GLNE y el «partido josefino», pues entre sus miembros se encontraron a altos funcionarios y cuadros medios de la administración de José I, junto con mandos militares del ejército napoleónico. Ahora bien, si se analiza el discurso fundacional de la obediencia, se observa una exaltación del régimen bonapartista — como no puede ser de otra manera considerando que la figura de Gran Maestre la ostentaba el Rey José I-, pero también de los principios masónicos y referencias a la identidad nacional española. Lo mismo ocurre con los Reglamentos de la logia Beneficencia de Josefina, donde las expresiones patrióticas se entremezclaban con los valores masónicos, reflejando además- que pertenecían a una logia que se consideraba profundamente española. Este sentimiento se pone de manifiesto en la documentación conservada, que revela los conflictos de reconocimiento entre las logias integradas por militares franceses adscritas al Gran Oriente de Francia (GOdF) y las de la GLNE.

El final de la GLNE vino de la mano de la caída del régimen bonapartista como resultado del devenir de la guerra de independencia y el subsiguiente exilio de todo aquel susceptible de ser acusado de masón o de colaborar con el gobierno intruso. Fue el tiempo de las delaciones y autoinculpaciones.

\section{La medalla de la logia Beneficencia de Josefina}
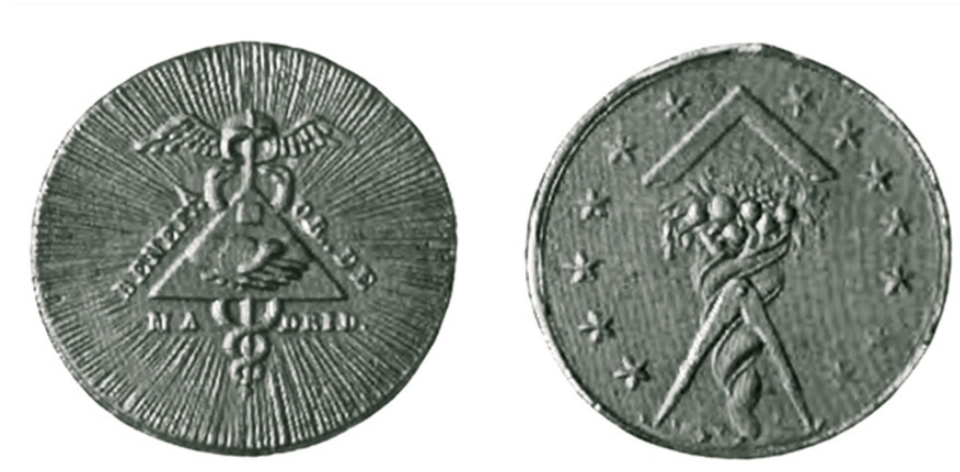

Fuente: Trésor de Numismatique et de Glyptique. París, 1840, https://play.google.com/store/books/details?id=oUI2AQAAMAAJ

\footnotetext{
32 Juan José Morales Ruiz, "Fernando VII y la masonería española", Hispania Nova. Revista de Historia contemporánea 3 (2003): 74-92, http://hispanianova.rediris.es/anteriores-3.htm

33 Marcelino Menéndez Pelayo, "La heterodoxia entre los afrancesados", en Historia de los heterodoxos españoles, vol. VII, I, http://www.cervantesvirtual.com/obra-visor/historia-de-los-heterodoxos-espanoles/html/
} 
El libro de actas, conocido como Libro de oro de la respetable logia de Beneficencia de Josefina ${ }^{34}$, es una de las fuentes que más información nos proporciona sobre la masonería de la GLNE. Entre los testimonios registrados en las actas nos importan particularmente las referencias a la medalla distintiva de la logia, cuya autoría es atribuida a Vicente Goldony.

De entre la información que nos proporciona señalamos aquellas anotaciones que hacen mención de la medalla:

1. En el Art. $6^{\circ}$ del acta correspondiente al seis de septiembre de 1810 podemos leer: "Se propuso hacer una medalla distintiva de esta R. $\therefore$ L.. cuya comisión se dió à nuestro muy querido $\mathrm{H} . \therefore$ Duro acordando que no se exigiese mas por ella, que su preciso coste, à los $\mathrm{HH} . \cdot$ que la pidiesen".

2. En el acta del día 19 del mismo mes y año, en el Art. $5^{\circ}$, se dice: "Se aprovo un modelo de los que presentó el Ven. $\because$ para la medalla distintiva de esta L. $\because$ y se acordó para ella una cinta color de naranja, con filetes blancos".

3. En el acta del día 18 de octubre del mismo año, en el Art. $6^{\circ}$ aparece: "El H. . Vicente Goldony, fue afiliado en esta L. $\because$ con general satisfacc. ${ }^{\mathrm{n}}$ de toda ella".

4. En el acta del día 18 de octubre del mismo año, en su Art. 11 figura: "Se presentaron, y repartieron las medallas distintivas de esta $\mathrm{L} . \therefore$ hechas por el $\mathrm{H}$. . Goldony, cuya generosidad no quiso exigir más que el coste, y costas, mereciendo por ella el general elogio".

Estos datos concretos, junto con el contenido general del libro, nos permiten conocer el autor, las circunstancias por las cuales se consideró necesario acuñarla, precisar que el 18 de octubre de 1810 fue la fecha exacta de datación de la medalla, así como el uso que se hacía de ella para obsequiar a distintas personalidades masónicas.

Afortunadamente se conserva en el Archivo Histórico Nacional un expediente inquisitorial ${ }^{35}$ de 1816 , en el que una testigo describe el estandarte de la logia:

(...) era de terciopelo de color naranja bordado de plata. Por un lado, tenía bordado el Sol de Oro con unas letras que decían "A la Orden de Josefina al Oriente de Madrid" bordadas también en plata, y un laurel formado de talco, y al otro lado un triángulo bordado en oro, encima del cual aparecía un palo largo con dos culebras

\footnotetext{
${ }^{34}$ En Manuel Corral Baciero, Libro de oro de la respetable logia de Beneficencia de Josefina (Oviedo: EntreAcacias, 2012); y también se puede consultar copia digitalizada del original en el portal PARES de la red de archivos españoles: http://www.pares.mcu.es

${ }^{35}$ En Manuel Júlvez Campos y Henar Pizarro Llorente, "Masonería bonapartista en Madrid (1812-1829) a través de los papeles inquisitoriales", en Masonería, revolución y reacción, coord. Ferrer Benimeli (Alicante: Diputación Provincial de Alicante e Instituto Alicantino de Cultura Juan Gil-Albert, 1990), tomo I, 71-78, se hace referencia a este expediente y a otros documentos inquisitoriales que aportan una descripción del templo, decoración de las estancias, mobiliario, y detalles sobre distintos personajes.
} 
enroscadas, y sobre esto una corona con dos alas a sus lados y abajo dos manos entrelazadas (...).

Estos símbolos son los mismos que ya figuraban en la medalla de la logia. Y no es casualidad, pues en el Libro de oro aparece una anotación correspondiente al artículo $9^{\circ}$ del acta del día veintidós de enero de 1811 en la que se dice que el venerable maestro encargó que se hiciera inmediatamente, constituyendo una comisión a tal efecto formada por él mismo y los hermanos Victoria y Goldony.

Las restantes referencias a la medalla figuran en catálogos numismáticos extranjeros. La encontramos citadas en tres fuentes acompañadas de la ficha descriptiva y, afortunadamente, en una de ellas aparecen las imágenes del anverso y reverso.

Estos documentos nos demuestran que mediado el siglo XIX el interés por el estudio y catalogación de esta expresión del arte masónico fue ya una constante entre coleccionistas y numismáticos europeos y estadounidenses. Reflexión ésta que debemos relacionar con lo tratado anteriormente sobre el coleccionismo masónico en España.

En el Trésor de Numismatique et de Glyptique ${ }^{36}$, publicado en 1840, la datación atribuida es del 31 de diciembre de 1809. Asimismo, los autores explican que no tienen conocimiento de la logia a la que pertenece la medalla y que el ejemplar incluido pertenece a la colección (Cabinet) de Madame Sœhnée. Pero, sin duda, la importancia de esta fuente radica en que es la única en la que figura una reproducción de la medalla, con la particularidad de que no aparece el asa superior para la cinta.

Theodor Merzdorf ${ }^{37}$, bibliotecario del Gran duque de Oldemburgo, publica el año 1851 en esa ciudad de la Baja Sajonia Die Denkmünzen der Freimaurerbrüderchaf, un catálogo numismático exclusivamente masónico en el cual se limita a reproducir someramente la información que sobre esta medalla ya se cita en el Trésor de Numismatique, pero sin incorporar ilustración alguna.

En The Medals of the Masonic Fraternity ${ }^{38}$, otro catálogo de medallas masónicas publicado por T.R. William Marvin -que fue miembro de la Sociedad Americana de Numismática y Arqueología-, se escribe que una de las principales fuentes de referencia que ha utilizado es la obra de Merzdorf. En la descripción de la medalla añade que es de plata, dato que no figuraba en las descripciones anteriores.

En cambio, no hemos encontrado referencia alguna entre los fondos de la Library and Museum of Freemasonry de la Gran Logia Unida de Inglaterra (UGLE), del Worcestershire Masonic Library and Museum Trust, de Les Musées de la Ville de París, de Le Musée de la

\footnotetext{
${ }^{36}$ Paul Delaroche, Henriquel Dupont y Charles Lenormant, Trésor de Numismatique et de Glyptique (París: Chez Rittner et Goupil Éditeurs, 1840), 80 y PL. XXXVII.

37 J. F. L. Theodor Merzdorf, Die Denkmünzen der Freimaurerbrüderchaft (Oldemburg: Verlag und Druck von Gerhard Stalling, 1851), 120.

${ }^{38}$ T.R. William Marvin, The Medals of the Masonic Fraternity (Boston: Edición del autor, 1880), 129.
} 
Franc-maçonnerie perteneciente al GOdF y de otros repositorios y bases de datos internacionales de numismática masónica. No obstante, otra institución donde es necesario investigar aún es el Departamento de monedas y medallas del Site Richelieu de la Bibliothèque Nationale de France, que se encuentra actualmente inmerso en un proceso de remodelación y reestructuración.

De esta medalla conocemos el autor, el contexto histórico y social en el que se inscribe, las circunstancias por las cuales se consideró necesario crearla, así como el uso que se hacía de ella. Sabemos por los catálogos en los que figura, que el diámetro de la medalla era de $36 \mathrm{~mm}$, que se realizó en plata, que tenía un asa en su parte superior - aunque esta no figura en las imágenes- y que en su día se decidió que incorporaría una cinta de color naranja con filetes blancos.

En cambio, desconocemos la ley de la plata empleada, su peso, así como la técnica de fabricación. Del mismo modo, ignoramos si la medalla se corresponde con las que se usan alrededor del cuello o que fuera del tipo galón con pasador para ser lucida prendida sobre el pecho.

Como quiera que en la descripción del estandarte aparecen los mismos símbolos representados en la medalla, podemos concluir que el conjunto iconográfico de la pieza confirma la intención con la que fue creada, es decir, ser un distintivo de la logia. De modo que la medalla surge para dar respuesta a una necesidad de índole práctica.

$\mathrm{Su}$ uso está orientado a servir como instrumento de identidad corporativa. En este sentido, es un objeto destinado a cumplir una doble función. Por un lado, intrínseca, en cuanto que refuerza el sentimiento de pertenencia al grupo y está dotada de una capacidad para integrar y cohesionar a los miembros de la logia. Y, por otro, extrínseca, en tanto que sirve de soporte diferenciador a la vez que actúa como elemento propagandístico y de comunicación institucional ${ }^{39}$.

Del mismo modo, la medalla se configura como un soporte didáctico. El mensaje exotérico que transmite la medalla es sencillo y directo, en consonancia con el modelo neoclásico característico de la masonería postrevolucionaria. Los principios masónicos, los valores éticos asociados a los signos representados -igualdad, fraternidad o generosidad-son evidentes. A su vez, el mensaje transcendente que todo objeto masónico tiene, sea ritualístico o no, queda sujeto a la interpretación individual. Más allá de que esté encriptado conforme a la naturaleza simbólica del código masónico, en esta medalla hay espacio para la hermenéutica ${ }^{40}$.

\footnotetext{
${ }^{39}$ Esta doble función de la medalla - en tanto que distintivo de la logia - queda reflejada en varios apuntes del Libro de oro, tanto cuando se dice que se repartieron entre los hermanos, como en las citas relativas a la entrega de ejemplares a miembros de otras logias y a personalidades de la obediencia.

${ }^{40}$ Para entender la función de los símbolos masónicos, y por extensión la funcionalidad de aquellos soportes en los que se integran, consultar: José Julio García Arranz, "5. Iniciación y perfección: la múltiple función de los
} 
No obstante, por el momento histórico y el contexto sociopolítico en el que se inscribe, descartamos la idea de que hubiera podido considerarse en algún momento como una hierofanía, actitud a la que estuvieron y están habituadas algunas corrientes masónicas para las que lo sagrado lo impregna todo ${ }^{41}$.

Respondiendo a la necesidad de clasificarla cronológicamente, podemos concluir que nos encontramos ante la primera medalla de la masonería española y, probablemente, la manifestación documentada más antigua del arte masónico español. Entendemos que este epígrafe no puede cerrarse quedando los aspectos que ya hemos enumerado susceptibles de seguir siendo investigados. En este sentido, ante la dificultad que para su análisis supone no disponer de un ejemplar de la medalla, consideramos el modelado infográfico en 3D y la reproducción facsimilar como instrumentos complementarios para el estudio y comunicación de todo aquello concerniente a esta medalla.

\section{Análisis numismático/iconográfico}

A la hora de estudiar el sentido simbólico de los glifos representados en la medalla, debemos considerar que nos encontramos ante una obra de arte masónico ${ }^{42}$.

La disposición de los motivos representados en esta medalla atiende a un esquema convencional. E, incluso, el conjunto lo podemos calificar de sencillo si lo comparamos con otras medallas francesas en las que la organización y riqueza de los elementos les confieren un singular valor expresivo. También podemos observar esta sencillez en las medallas masónicas españolas de la segunda mitad del siglo que se han conservado.

Un aspecto importante es el hecho de que en la medalla no figura ninguno de los frecuentes lemas y divisas utilizados por los masones y de los que tenemos bastantes ejemplos en las medallas francesas.

\section{Anverso:}

- En primer plano y en el centro del campo, un triángulo rectángulo apoyado en la hipotenusa.

- En su interior, dos manos enlazadas y, sobre éstas, un cuadrado.

\footnotetext{
símbolos masónicos”, en Simbolismo masónico. Historia, fuentes e iconografia (Vitoria-Gasteiz: Sans Soleil Ediciones, 2017), 101-105.

${ }^{41}$ Consultar: Sánchez Ferré, La masonería. Símbolos, doctrinas e historia (Sta. Cruz de Tenerife: Ediciones Idea, 2015).

${ }^{42}$ En este sentido, el testimonio, la narración de los glifos (del verbo griego $\gamma \lambda \nu \varphi \varepsilon i ̃ v:$ grabar en hueco, tallar) representados, no puede disociarse de su sentido simbólico (a su vez de $\sigma 0 \mu \beta a ́ \lambda \lambda \lambda \varepsilon ı v$ : lanzar y reunir). Y esto es así porque —como reza el aforismo- en masonería todo es símbolo y alegoría.
} 
- En segundo plano, detrás del triángulo, un caduceo alado en el que se distingue el remate en forma de corona y asoman dos cabezas de serpiente.

- La leyenda discurre sobre los tres lados del triángulo, recurriendo a la costumbre masónica de abreviar las palabras.

- En último plano, un fondo radiante que nace del triángulo y abarca radialmente todo el campo de la medalla.

- Carece de gráfila y listel.

\section{Reverso:}

- En primer plano, y ocupando el tercio superior del campo, una escuadra centrada verticalmente con el vértice apuntando al exterior.

- En la parte inferior, un compás abierto en ángulo de $45^{\circ}$.

- En segundo plano, bajo el compás, un cuerno de la abundancia dispuesto verticalmente.

- Rodeando la composición, a la izquierda, seis estrellas de cinco puntas y, a la derecha, siete. Los dos grupos bordeando circularmente el listel.

- El fondo del campo es liso y no presenta gráfila.

\section{Interpretación iconológica}

Triángulo radiante:

También conocido como «Delta luminoso» (por la letra griega " $\Delta$ "), aunque aquí no esté representado un triángulo equilátero, se dispone en el oriente del templo masónico sobre el sitial conocido como «Trono del Rey Salomón», ocupado por el Venerable Maestro, que es la figura encargada de conducir los trabajos y ceremonias. De origen profundamente judeocristiano, simboliza el verbo como principio creador, esto es, al Gran Arquitecto del Universo (GADU), y por extensión, la luz como alegoría del conocimiento universal en tanto que los rayos alumbran en todas las direcciones.

\section{Caduceo alado:}

Se incorpora al corpus iconológico masónico vinculando la antigüedad clásica con la masonería. Parecido a la asimilación de la tradición pitagórica o del dios Jano. Las serpientes enlazadas son un elemento que se acostumbra a relacionar con el concepto masónico de dualidad y, también, de unión. Las alas representan la elocuencia y también la libertad. La corona puede expresar el vínculo con la monarquía de José I. Asimismo, es un símbolo vinculado estrechamente con la tradición hermética y la alquimia, tradiciones de las que se 
ha nutrido profusamente el imaginario masónico y, particularmente, el Rito Escocés Antiguo y Aceptado (REAA). Más allá de las distintas interpretaciones, estamos ante un símbolo polisémico, aspecto éste muy del gusto masónico que encuentra en la hermenéutica el vehículo perfecto para estudiar sus misterios.

Piedra cúbica:

Simboliza el ideal de perfeccionamiento. Empeño al que se debe aplicar durante su vida todo masón, aun sabiendo lo imposible de alcanzarlo desde la concepción imperfecta de la naturaleza humana. Dependiendo del rito practicado, su ubicación será diferente dentro del templo. También la cara superior podrá prolongarse en forma piramidal (cubo apuntado). Esta piedra, junto con otras de singulares formas utilizadas en arcos o bóvedas trabajadas por los albañiles o canteros de la masonería operativa, forman parte de los rituales de otros grados masónicos de tradición inglesa. Por ejemplo, en la orden masónica del Real Arco, ahora como hexaedro, forma parte del conjunto de sólidos platónicos dispuestos sobre la representación de la cripta abovedada del templo de Salomón, mientras que en la orden masónica de los Maestros Masones de la Marca durante sus rituales se utiliza junto con otras de formas singulares dotadas cada una de su particular sentido y significado.

\section{Alianza:}

Conocido como dextrarum iunctio -apretón de manos ceremonial de los contrayentes durante el matrimonio romano-, se aplica en heráldica desde antiguo y en Francia se denomina $\mathrm{Foi}(\mathrm{Fe})$. Es un símbolo que evoca compromiso, fidelidad y fraternidad, siendo un gesto que, realizado de la forma adecuada en sus distintas variantes, se emplea desde los inicios de la masonería especulativa como señal de reconocimiento.

Leyenda:

Este elemento no es propiamente un símbolo, ni una alegoría, ni un lema o una divisa. La incluimos por la costumbre masónica de usar abreviaturas seguidas de los tres puntos $(\therefore)$, con el objeto de enmascarar determinadas palabras.

\section{Escuadra:}

Se trata de uno de los elementos del imaginario masónico que más ha transcendido al mundo profano. Pertenece al conjunto de símbolos adoptados de las herramientas de la masonería operativa. En la especulativa simboliza la rectitud y moralidad. Por esta razón le corresponde al Venerable Maestro de la logia lucirla prendida en su collarín. Está considerada la primera de las «joyas móviles», junto con el nivel y la plomada que lucen el Primer y Segundo Vigilantes respectivamente. Los masones hablan de una «conducta escuadrada». Y también está presente en el transcurso de las ceremonias cuando se desplazan por el templo 
«escuadrando», la logia, o se sitúan «al orden», formando escuadra con algunos de sus miembros o extremidades.

Compás:

Símbolo, como la escuadra, tomado del oficio tradicional. Es muy frecuente encontrarlos representados de forma superpuesta. El compás habilitaba al maestro cantero o albañil para, con exactitud y precisión, fijar y determinar los límites y las proporciones de las partes de una construcción. Para el masón simboliza la infalible e imparcial justicia que el GADU aplica a su conducta según los límites del bien y el mal que les ha transmitido. Al igual que la escuadra, se dispone y se utiliza de diferentes formas.

\section{Cornucopia:}

Es un símbolo asimilado por la cultura occidental y podemos encontrarlo en infinidad de representaciones artísticas o, incluso, aplicado como signo gráfico y paragráfico. El significado masónico asociado es el de prosperidad, generosidad y caridad. En la joya del Maestro de Banquetes del REAA se representa bajo un compás abierto, mientras que en el rito de Emulación (RE) es el atributo del Experto (steward).

Estrellas:

Aparecen formando parte de la decoración del techo del templo como expresión de la cosmogónica mitología masónica. Junto con la luna y el sol, forman parte del repertorio relacionado con la astronomía, por lo tanto, vinculadas directamente con el grado de compañero en el que se completa el estudio del «trivium et cuadrivium». La estrella flamígera es la forma ritualística por excelencia, habitualmente conteniendo inscrita la letra «G». Representada como el pentáculo pitagórico, hace referencia a la proporción áurea como ley universal emanada del GADU. La disposición en grupo y alineadas implica igualdad, fraternidad y comunidad.

\section{Vicente Goldony: diamantista y masón}

La vida del veneciano de nacimiento Vicente Goldony Bibiani transcurrirá en Madrid, a caballo de los siglos XVIII y XIX, con el exilio francés de por medio.

Nos encontramos ante uno de esos personajes que se esconden en la letra pequeña de la historia. Para documentarnos sobre su vida y obra hay que recurrir a un minucioso rastreo por todo tipo de registros: desde las publicaciones periódicas de su tiempo, pasando por las obras que abordan la historia de la joyería y orfebrería madrileña, sin olvidar los archivos parroquiales, gremiales, históricos, etc. 
El primer documento donde hallamos referencias a Goldony Bibiani es en el Libro de Oro, en el que aparece como autor de la medalla. El estudio minucioso de las actas nos aporta interesantes datos sobre la biografía masónica de nuestro hombre, pero también nos ofrece su firma. Este será un hallazgo singular por cuanto conferirá personalidad a un dato que hasta el momento no pasaba de tener naturaleza literaria.

Para entonces el veneciano ya era una persona relativamente conocida en aquel Madrid que aglutinaba a una población algo superior a los 175.000 vecinos. Tenía abierto un comercio en los bajos del mismo inmueble en el que residía y donde ejercía el oficio de diamantista y comerciaba con el género propio de un platero de oro ${ }^{43}$.

$\mathrm{Su}$ consideración profesional debía tenerse en alta estima pues en el Archivo de Palacio se encuentran apuntes de varios pagos correspondientes a unos artículos de oro adquiridos por el infante don Antonio Pascual de Borbón -hijo de Carlos III-, así como diversas facturas libradas a su nombre en el Archivo del Ducado de Osuna ${ }^{44}$.

En diversos avisos de prensa figura su domicilio como contacto de referencia, y también lo cita De Mesonero Romanos cuando enumera los personajes que, desde el balcón de su casa, contemplaban los disturbios del Motín de Aranjuez ${ }^{45}$ :

(...) Y mientras por fuera continuaba la algazara todo aquel día, y se aumentaba y enloquecía con las deseadas noticias sucesivas de la captura del reo, de la abdicación de Carlos IV y exaltación al trono del Príncipe D. Fernando, mi casa se llenaba de amigos y vecinos de la reducida calle del Olivo bajo (que así se llamaba entonces el trozo que media entre las del Carmen y la Abada), y que formaban por este solo concepto una cordial sociedad; pero como sería largo y enojoso el citarlos a todos, sólo apuntaré aquellos que en esta ocasión tomaron más parte en las conversaciones y algazara común. (...) el diamantista D. Vicente Goldoni; el agente D. Tadeo Sánchez Escandón, y el presbítero D. Manuel Gil de la Cuesta, vecinos o inquilinos de mi padre en su propia casa. (...).

Su destino se torció con el regreso de Fernando VII, de suerte que se verá en la necesidad de convocar concurso de acreedores y -posteriormente- exiliarse, compartiendo así el camino con otros españoles -a decir de algunos 4.000 y de otros hasta 12.000-. Entre

\footnotetext{
${ }^{43}$ Sobre los plateros madrileños, consultar la obra del profesor José Manuel Cruz Valdovinos. Para analizar el panorama de la platería madrileña durante este periodo ver: José Manuel Cruz Valdovinos, Los plateros madrileños. Estudio histórico-jurídico de su organización corporativa (Madrid: Edición del Gremio de Joyeros y Plateros de Madrid, 1983) y "La Platería del siglo XIX", en Historia de las artes aplicadas e industriales, coord. Antonio Bonet Correa (Madrid: Cátedra, 2008), 149.

44 "Tasaciones, cuentas, libramientos y recibos de plateros y joyeros por objetos hechos o vendidos a las Casas de Osuna, Gandía, Benavente, etc. (1800-1827): Cuentas de alhajas de Vicente Goldoni”, Archivo Histórico de la Nobleza. Signatura: OSUNA, CT.386, D.11.

${ }^{45}$ Ramón De Mesonero Romanos, Memorias de un setentón, natural y vecino de Madrid (Madrid: Renacimiento, 1926).
} 
ellos estaban un buen número de ilustres afrancesados ${ }^{46}$, como Meléndez Valdés o Leandro Fernández de Moratín ${ }^{47}$, y no pocos masones.

Seguramente se le despejaría cualquier duda sobre hacia donde orientar su futuro a la luz de los acontecimientos relatados por El Diario de Mallorca el 24 de diciembre de 1812, donde informaba que el 25 de septiembre, en Madrid, fueron llevadas al Retiro diversas personas -"presos por traidores"-, señalando entre ellas al "diamantista Goldoni (sin valerle sus diamantes)".

No tenemos constancia de cómo se desenvolvió en el país vecino, pero sí disponemos del expediente relativo a la investigación sobre su conducta política durante el gobierno francés, que se abrió en 1815 a instancia de su mujer-María Raseti-, con la intención de que se permitiera regresar de Francia a su marido, para que pudiera "incorporarse en el servicio del Rey nuestro señor". El documento no tiene desperdicio y ofrece interesantes ejemplos de la naturaleza humana, poniendo sobre el papel actitudes tan españolas como la envidia o la venganza, pero también de perspicacia e ingenio ${ }^{48}$.

Entre los acontecimientos narrados llama la atención el testimonio de un testigo, que describía a nuestro diamantista: "de una estatura como de dos varas, algo recio".

Desconocemos el sentido final del proceso. El caso es que las siguientes referencias que hemos hallado pertenecen a los primeros años de la década de los 20 , cuando se publicaron anuncios y avisos donde figuraba su nombre o su comercio. Además, una de las facturas de las que hemos dado cuenta estaba fechada en 1823.

Pero no todo iban a ser sinsabores. Hemos visto cómo Goldony Bibiani se repuso de sus desgracias y levantó de nuevo su negocio. Asimismo, prueba de su tenaz carácter y

\footnotetext{
${ }^{46}$ Miguel Artola, en Los afrancesados (Madrid: Sociedad de Estudios y Publicaciones 1953, y Alianza Editorial, 2008), estudia, desde una posición renovadora y alejada de los tópicos acuñados por la tradición historiográfica decimonónica, la ideología política, los diferentes grados de afección al nuevo estado y el papel desempeñado por los afrancesados frente a la coyuntura en la que se encontraba el país tras la renuncia de Carlos IV y la invasión napoleónica. Con posterioridad, otros historiadores, como Juan López Tabar en Los famosos traidores. Los afrancesados durante la crisis del Antiguo Régimen (1808-1833) (Madrid: Biblioteca Nueva, 2001), han desarrollado la idea de que, frente al colapso del Antiguo Régimen, los afrancesados se situaron como intermediadores entre los liberales y los representantes del absolutismo y el clero más conservador. Por su parte, Francisco Javier Ramón Solans en "El legado historiográfico de Miguel Artola", Rolde. Revista de Cultura Aragonesa 124-125 (2008): 4-11, estima necesaria "una revisión crítica" que defina las características de este grupo, acompañada de una renovación léxica junto con una nueva propuesta metodológica, cosa que no hace Tabar, limitándose a asumir "canónicamente los presupuestos y categorías analíticas" planteadas por Artola.

${ }^{47}$ Pedro Ortiz Armengol, madrileño de nacimiento, diplomático, académico, historiador, pero sobre todo galdosiano, - a decir del escritor, editor y periodista canario Juan Cruz en la necrológica que le dedica en El País del 16 de marzo del 2009-, nos habla de Vicente Goldony en un artículo que publica en 1975 la revista Estudios Románticos y que lleva por título "Viajes y entredichos de Moratín en Francia". En el artículo, Ortiz Armengol aventura como probable que el diamantista don Vicente Goldoni tuviera un parentesco con el dramaturgo veneciano Carlo Goldoni, y considera más que probable que hubiera una relación profesional con los Fernández de Moratín orfebres.

48 "Expediente relativo a la investigación sobre la conducta política de Vicente Goldony durante el gobierno francés", Archivo Histórico Nacional. Signatura: CONSEJOS, L.1404, Exp.24.
} 
maestría en el oficio, perseveró hasta el punto de ser elegido "Maestro Aprobador de oro del Colegio de San Eloy de la Villa de Madrid" en 1829. Incluso, su hijo Juan alcanzó a ser aprobado maestro platero de oro de esa institución en 1832, el mismo año del fallecimiento de su progenitor ${ }^{49}$.

Hasta su último esfuerzo procuró velar por el futuro de su comercio y que su apellido continuara vinculado al oficio.

\section{El jeton de presencia en la logia Beneficencia de Josefina}

Como hemos dicho anteriormente, el Libro de oro de la respetable logia de Beneficencia de Josefina nos proporciona valiosa información sobre los hábitos y maneras de proceder que se seguían tanto en la logia como en la obediencia. Algunas de aquellas costumbres se han conservado con el paso del tiempo y están plenamente vigentes en la actualidad. Sin embargo, otras han ido cambiando con el paso del tiempo o, incluso, han caído en desuso.

Una norma que se observaba en las logias francesas durante el siglo XIX, y hasta bien entrado el XX, consistía en el uso de los conocidos como jetons de presence, que podemos traducir como «fichas de presencia». Actualmente, en el mundo profano, esta costumbre se ha convertido en la remuneración económica denominada "dietas", que se percibe por asistir a determinadas reuniones.

En el contexto masónico el significado era un poco diferente. La finalidad que tenía esta práctica era beneficiar a aquellos iniciados de la logia que acudían regularmente, al mismo tiempo que se penalizaba a los que se ausentaban. A tal efecto, los talleres emitían sus propios jetons de carácter interno y se les asignaba un valor económico. Esta cantidad se sumaba a la "capitación ${ }^{50 "}$ que el miembro abonaba a la logia. En cada reunión, a los asistentes se les entregaba un jeton, de manera que al término del año masónico se podía solicitar al tesoro de la logia el reembolso de la suma de los jetons acumulados. Los jetons también se entregaban a los componentes de otras logias que acudían de visita y estos solían conservarlos como recuerdo.

\footnotetext{
${ }^{49}$ El Archivo del Gremio de Joyeros y Plateros de Madrid conserva la documentación relativa a este periodo de la actividad del antiguo Colegio de San Eloy y de sus miembros. En José Manuel Cruz Valdovinos, "Plateros aprobados e incorporados al Colegio de San Eloy de Madrid", en Estudios de Platería. San Eloy 2012, coord. Jesús Rivas Carmona (Murcia: Universidad de Murcia, 2012), 168; y Cruz Valdovinos, "Relación de plateros activos en Madrid en 1861", en Estudios de Platería. San Eloy 2013, coord. Rivas Carmona (Murcia: Universidad de Murcia, 2013), 166, hemos encontrado importante información para investigar sobre la biografía de Vicente Goldony y su entorno profesional.

${ }^{50}$ Del latín caput, capitis, cabeza. Cantidad de dinero que los miembros de una logia abonan periódicamente en concepto de contribución al sostenimiento de la logia y obediencia. En español usamos la expresión "por cabeza" con el mismo sentido.
} 
Actualmente, estas fichas monetiformes son objeto de colección, existiendo un mercado específico para estas piezas. Es frecuente encontrarlos en lotes de las subastas numismáticas, donde los más raros alcanzan altas cotizaciones. Como ya indicamos, la exonumia es la especialidad de la numismática que se ocupa de su estudio.

En la logia Beneficencia de Josefina se introduce esta costumbre, según queda reflejado en el artículo $3^{\circ}$ del acta del 13 de diciembre de 1810, donde podemos leer: "Presentó nuestro Ven. $\cdot$ las fichas, que deven acreditar la presencia de los $\mathrm{HH} . \therefore$ en nuestras sesiones, y se acordó que principie el uso de este Art. $\cdot$ del Rglam. ${ }^{\text {to }}$ en la inmediata". Puede entenderse que se pusiera en práctica esta medida, habida cuenta de las anotaciones recogidas en distintas actas anteriores, instando repetidamente a los miembros de la logia a que liquidasen las deudas contraídas con el tesoro de la logia.

\section{Una medalla honorífica de la logia Beneficencia de Josefina}

Otra medalla de esta logia que recoge el Libro de Oro es la que se entregó al Venerable Maestro como muestra “del tierno amor" y "justa gratitud” que le profesaban sus hermanos, según queda recogido en el artículo $7^{\circ}$ del acta correspondiente al 25 de marzo de 1811. En el texto figura que se trataba de una "medalla de honor" y que era de oro. Y, a continuación, se describía en los siguientes términos:

Contenía en la una faz de un triángulo de oro al aire, el símbolo de la gratitud, representada en un León, que tiene abrazado cariñosam. ${ }^{\text {te }}$ à un perrillo, que le está lamiendo los ojos, y sobre el geroglifico, este lema: La Gratitud. En el reverso del mismo triangulo una inscripc. ${ }^{\mathrm{n}}$ que dice: La R. $\therefore$ L. $\therefore$ de la Benef. $\therefore$ de Josef.. à su I. Ven. $\therefore$ el E. $\therefore$ H. $\therefore$ Benito.

La costumbre de otorgar estas distinciones honoríficas en forma de medalla persiste en la masonería actual. Tanto su concesión como su lucimiento suele estar normativizado en los reglamentos internos de cada logia y -también- en los de la obediencia.

Como en este caso se trata de una distinción, la clasificación de la pieza entraría dentro de la disciplina numismática denominada falerística.

La medalla de la logia Napoleón el Grande 


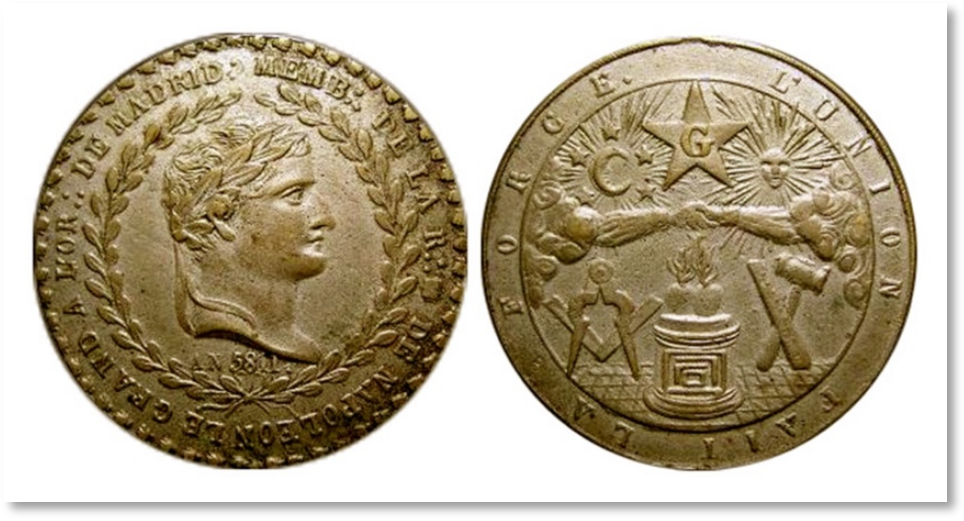

Fuente: Colección privada "elverno". California, EE. UU. https://www.omnicoin.com/coin/898462

Otra de las logias que integraban la GLNE era la Respetable Logia de Napoleón el Grande. Y, al igual que el taller Beneficencia de Josefina, emitió su propia medalla.

De ella conocemos algunos datos proporcionados por diversas fuentes y testimonios, entre ellas las citas que aparecen en el Libro de Oro.

Los primeros testimonios que tenemos de esta medalla son las referencias que aparecen en los catálogos numismáticos extranjeros, que también citan la medalla de la logia Beneficencia de Josefina ${ }^{51}$. Una diferencia significativa entre ambas es que en esta figura la fecha de emisión y, por lo tanto, no presenta los problemas de datación de aquella.

De la medalla de la logia Napoleón el Grande se conservan varios ejemplares en diferentes metales y aleaciones. Ésta es una costumbre que se aprecia en otras medallas masónicas francesas y -más allá- podemos decir que se trata de una práctica frecuente en el ámbito de la medallística.

Un ejemplar de esta medalla acuñada en plata salió a subasta en diciembre de 2007 en la firma francesa «Cannes Enchères. Hôtel des Ventes», rematándose la puja en $2.150 €$. También de plata es el calco de esta medalla que figura en el catálogo Medallas Españolas Masónicas $^{52}$ de Herrera Chiesanova, ya citado.

Además, como hemos señalado, se conservan - cuando menos- otras dos piezas: una en bronce perteneciente a la colección privada de un coleccionista californiano; y otra en cobre sobredorado, que figura en el catálogo de numismática masónica francesa editado por la Maison Platt ${ }^{53}$. Marc Labouret, autor de la obra, tras describir la medalla, añade algunos

${ }^{51}$ Delaroche, Dupont y Lenormant, "Trésor de Numismatique et de Glyptique", 103; Merzdorf, "Die Denkmünzen der Freimaurerbrüderchaft", 120; y Marvin, "The Medals of the Masonic Fraternity", 129.

${ }^{52}$ Herrera Chiesanova, "Medallas españolas masónicas", 23.

${ }^{53}$ Marc Labouret, Les métaux et la mémoire. La franc-maçonnerie française racontée par ses jetons et médailles (París: Maison Platt Éditeur, 2007), 337. 
comentarios que reproducimos, en los que demuestra su desconocimiento sobre la historia de la masonería española y la procedencia de la medalla:

Loge inconnue du Répertoire. L'Espagne n'a jamais été complètement conquise par les troupes napoléoniennes, et n'a pas été intégrée au grand Empire. Dans un pays où l'Inquisition avait jusqu'alors efficacement pourchassé la Franc-maçonnerie, les loges militaires françaises représentent sa première implantation réelle. La greffe ne prendra pas; les patriotes ne mouraient-ils pas au cri de "A bas la liberté"? Notre médaille appartient à cette présence éphémère ${ }^{54}$.

\section{Análisis numismático / iconográfico}

Esta medalla presenta un estilo marcadamente francés. De hecho, en el anverso está representado Napoleón I en un retrato de perfil, las leyendas están escritas en ese idioma y el esquema compositivo sigue el modelo característico de las medallas napoleónicas del Primer Imperio, si bien el reverso presenta un tratamiento gráfico carente del detallismo y realismo de aquellas.

Comparándola con otras medallas masónicas francesas del mismo periodo, observamos que se asemeja a un tipo que se distingue por la profusión de los símbolos representados en el reverso, lo que manifiesta una especial intención didáctica. Esta condición se ve reforzada por el recurso de incorporar un lema en el reverso.

Por la palabra abreviada "MEMB... , que figura en la leyenda del anverso, puede deducirse que es una medalla de membresía, tiene una finalidad de identidad corporativa. Esta observación también la reseña Marvin en The Medals of the Masonic Fraternity.

Anverso:

- Ocupando la mayor parte del campo, está el retrato de perfil mirando hacia la derecha de Napoleón I, adornado con una corona de laurel sujeta con una cinta que cae sobre el cuello.

- Una corona de laurel que rodea completamente el retrato.

- Debajo del perfil y sobre la corona, aparece la leyenda con la fecha en datación masónica: “AN 5811” (1811).

\footnotetext{
${ }^{54}$ Logia desconocida en el repertorio. España nunca fue conquistada completamente por las tropas napoleónicas, y no se integró en el gran Imperio. En un país donde la Inquisición había perseguido hasta entonces eficazmente a la masonería, las logias militares francesas representan su primera implantación real. El injerto no prenderá; ¿no murieron los patriotas al grito de "Abajo la libertad"? Nuestra medalla pertenece a esta efímera presencia [mi traducción].
} 
- La leyenda discurre alrededor del campo recurriendo a la costumbre masónica de abreviar las palabras. En ella se identifica el nombre de la logia y la localidad de procedencia.

- La gráfila responde a un motivo floral. Carece de listel.

Reverso:

- El campo está enmarcado por un listel y se encuentra dividido horizontalmente en dos partes por el motivo conocido como «alianza» (dextrarum iunctio), cuyos brazos nacen de sus respectivas nubes.

- Ocupando la mitad superior del campo, a la izquierda, está representada la luna creciente con perfil humanizado mirando hacia la derecha, radiante y rodeada de cinco estrellas de cinco puntas.

- En el centro de la parte superior y en primer plano, una estrella de cinco puntas con una letra «G» en el centro.

- A la derecha de la mitad superior del campo, un sol radiante de rostro humano mirando de frente.

- En la parte inferior izquierda figura un compás abierto en ángulo de $45^{\circ}$ sobre una escuadra con el vértice apuntando hacia abajo.

- En el centro, y sobre un pavimento de cuadrados representados en perspectiva, de forma que definen una escena, se sitúa un altar con decoración lineal. Sobre él, dos corazones flameantes.

- A la derecha se representan oblicuamente un mazo (o mallete) bajo una regla.

- Recorriendo el exterior del campo figura la leyenda en francés: L'UNION FAIT LA FORCE.

- Rodeando el exterior del reverso se incorpora otro listel.

Puede apreciarse que la parte superior de la medalla ha sido manipulada. Este detalle, que también está presente en otro ejemplar, nos lleva a considerar la posibilidad de que originalmente- tuviera incorporada un asa, o que se acostumbrara a soldarle una que se haya eliminado con posterioridad.

\section{Interpretación iconológica}

El conjunto de elementos representados en el reverso de la medalla no aparece distribuido aleatoriamente. El ordenamiento de los símbolos responde a una voluntad de 
describir la escenografía idealizada de un espacio masónico encerrado en la forma circular del objeto soporte. La medalla cuenta más de lo que a primera vista pudiera parecer.

Estrellas:

Este símbolo ya lo comentamos cuando estudiamos la medalla de la logia Beneficencia de Josefina. Aquí su número es de cinco, esta cifra asociada a la estrella con la letra «G», podría interpretarse como una velada alusión al segundo grado.

Luna y sol:

Estos dos símbolos aparecen humanizados. De esta forma, que no es exclusiva de la masonería, el rostro les confiere personalidad y transcendencia. El lugar que ocupan respectivamente no es arbitrario, sino que están dispuestos de la misma manera que en el oriente del templo masónico. El significado es muy amplio, son símbolos marcadamente polisémicos, pero el que guarda relación con la escenografía representada en la medalla, es aquel que habla del periodo durante el cual desarrollan sus trabajos los masones en las logias de San Juan, de mediodía en punto a medianoche.

\section{Alianza:}

Figura representada de una forma frecuente en otras medallas de la masonería francesa, surgiendo ambos brazos de sus respectivas nubes. El significado hace referencia al alto sentido o elevada naturaleza del vínculo fraternal.

Escuadra y compás superpuestos:

Ya hemos hecho referencia a estos dos símbolos al describir los que aparecen en la medalla de la logia Beneficencia de Josefina. A diferencia de aquella, aquí aparecen formando un subconjunto, representados conforme al uso en el tercer grado.

\section{Mazo y Regla:}

Estamos ante un caso como el anterior. De forma deliberada, se han representado conjuntamente dos de las herramientas propias del primer grado: la regla de 24 pulgadas que representa las 24 horas del día- y el mazo que, a su vez, nos habla de la voluntad y la fuerza de la conciencia para perseverar en la progresiva autotransformación.

Altar y corazones flameantes:

Este símbolo sitúa la escena dentro de la tradición escocista a la que pertenece la logia y la obediencia. El corazón flameante que hace referencia al fervor amoroso hunde sus raíces en la tradición crística o cristiana, en conjunción con la alquímica espiritual europea. De hecho, en esa figura también podría verse un hornillo de atanor alquímico. Sin embargo, el 
mencionado motivo no se ha incorporado al corpus iconológico de la masónica española. Este símbolo da nombre y aparece representado sobre un altar en las medallas de las logias escocistas parisinas Les cours unis (1808), o Les cours sinceres (Labouret no. 179). En la medalla de la logia Les cours unis de Dieppe (1805) son tres los corazones ardientes representados, mientras que en la medalla acuñada por la logia La Parfaite Unión de Rennes (1804) es un solo corazón el que está situado sobre el altar.

Pavimento:

Este elemento no está representado como un símbolo o motivo propiamente. Sin embargo, es perfectamente identificable con el pavimento mosaico de cuadrados blancos y negros que alfombra el templo masónico. Su significado expresa tradicionalmente la dualidad en su concepto más amplio. En la medalla, representado abajo y en perspectiva, cumple la función de proporcionar profundidad a la escena.

\section{Una medalla honorífica de la logia de Santa Julia}

Esta logia la conocemos principalmente por el Libro de arquitectura de la logia Santa $J_{u l i a}{ }^{55}$ y por las referencias a ella que aparecen en el Libro de oro.

De esta medalla no hemos encontrado referencia en catálogos numismáticos, lo que en principio no puede extrañarnos dado que su origen responde a una necesidad eventual, costumbre frecuente en las logias, como ya hemos visto. Toda la información relativa a esta medalla es la que aparece en el Libro de arquitectura.

En la «plancha» que hace referencia a los trabajos celebrados en la sesión del 28 de mayo de 1810, figuraba la propuesta para organizar un premio a la mejor memoria que se presente sobre la siguiente pregunta: “¿Quál será la influencia de la Mria. ‘ en la felicidad de la España?”.

En los artículos que desarrollaban las condiciones del premio se describían las medallas, de oro y de plata, que se entregarían al ganador y finalista respectivamente. Las medallas tendrían el peso de una onza ${ }^{56}$. Por un lado, aparecerían las «armas de la logia» junto al nombre del agraciado. Y, por el otro, el sol -como emblema de la masonería-, junto a la inscripción "Ilumina y vivifica".

De la iconografía representada en el emblema de la logia —o «armas de la logia»—, tenemos una somera referencia en una nota a pie de página que aparece en Historia de las

\footnotetext{
${ }^{55}$ Manuel A. De Viado. Colección de piezas de arquitectura trabajadas en el Taller de Santa Julia (Madrid, 1812).

${ }^{56} \mathrm{La}$ onza castellana equivale a $28^{\prime} 75576 \mathrm{~g}$.
} 
sociedades secretas antiguas y modernas en España ${ }^{57}$, donde el autor escribe: "Tiene en la portada un sello muy bien grabado en cobre con todas las alegorías masónicas que dice [...] de San Juan de Escocia bajo el título distintivo de Santa Julia al O. $\therefore$ de Madrid: El signo $[\ldots]^{58}$ equivale a logia".

Más adelante se añade que los premiados serán declarados miembros honorarios de la logia. Esto es, la obtención del premio supone, además de ser galardonado con una medalla, hacerse merecedor de una distinción honorífica. De modo que estaríamos ante otro ejemplo numismático cuyo estudio entraría dentro del ámbito de la falerística, puesto que se establece un vínculo entre el mérito literario, el galardón en forma de medalla, y la concesión de un privilegio.

\section{Conclusiones}

1. Este trabajo de investigación supone la definición de la unidad documental formada por el conjunto de aquellas medallas de la GLNE de las cuales hemos encontrado referencias. Unidad documental susceptible de ampliarse con aportaciones tanto propias, como por parte de otros investigadores.

2. En esta unidad documental están representadas tres categorías numismáticas: dos de carácter identitario (medallística), un jetón de presencia (exonumia) y otras dos honoríficas (falerística). El conjunto de estas cinco medallas nos habla de la asimilación de las costumbres masónicas en el seno de las logias de la GLNE.

3. Hemos constatado que tres logias de la GLNE recurren al uso de medallas masónicas para atender a diferentes necesidades del taller. Conviene preguntarse si tanto las logias, como la misma obediencia, emitieron otras medallas.

4. Es preciso continuar la investigación emprendida con el objeto de documentar algún ejemplar de la medalla de la logia Beneficencia de Josefina.

\footnotetext{
${ }^{57}$ Vicente de la Fuente. "La lógia «Santa Julia» de Madrid: descripción de la fiesta que hubo en ella el día 28 de mayo de 1810.". En Historia de las sociedades secretas antiguas y modernas en España y especialmente de la Franc-Masoneria, ed. Imprenta D.R.P. INFANTE (Madrid: 1874), tomo I, 115-119.

${ }^{58}$ Este signo en el original aparece con los corchetes en disposición vertical con los tres puntos en medio, hemos optado por representarlo con los corchetes alineados horizontalmente por imperativo tipográfico.
} 
5. La producción de estas medallas señala el nacimiento de la numismática masónica española, actividad que continuará durante el siglo XIX — como en el resto del orbe masónico- hasta la actualidad.

6. Es conveniente investigar la historia del coleccionismo numismático masónico en España y su estado actual.

7. Interesa investigar la historia de la producción nacional de medallas y joyas masónicas, así como el comercio interior y exterior de este tipo de productos.

8. Es pertinente considerar las nuevas tecnologías informáticas CAD/CAM y de prototipado rápido como recurso al servicio de la investigación y comunicación de la numismática masónica española.

9. Creemos necesario la normalización del estudio de la historia de la numismática masónica española en el contexto general de la historia del arte español, en tanto que representa una parte olvidada de nuestro patrimonio artístico.

\section{Bibliografía}

Amador Carretero, María Pilar. "La fotografía como control policial". En La masonería española: represión y exilios. Coordinado por José Antonio Ferrer Benimeli. Zaragoza: CEHME, 2011.

Amate Martínez, María del Carmen. Entre la historia y el mito: La Masonería española a través de la fotografía. Catálogo de exposición. Almería: Instituto de estudios almerienses, 2009.

Arias, Miguel y Jiménez, Alfonso D. Joyas masónicas. Madrid: Iberediciones, 1992.

Arola, Raimon. Simbolismo del templo. Barcelona: Ediciones Obelisco, 2001.

Artola, Miguel. Los afrancesados. Madrid: Alianza Editorial, 2008.

Boletín Oficial del Gran Oriente de España. 15 de mayo de 1873, 1 de julio de 1873 y 15 de julio de 1873.

Centro de Estudios Históricos de la Masonería Española. http://cehme.com/

Conde Martel, Consuelo. "Aspectos simbólicos de los sellos masónicos en Canarias y de la logia Añaza”. Tebeto: Anuario del Archivo Histórico Insular de Fuerteventura 2 (1989): 129-178.

Corral Baciero, Manuel. Libro de oro de la Respetable Logia de Beneficencia de Josefina. Oviedo: EntreAcacias, 2012. 
Cruz Valdovinos, José Manuel. "La Platería del siglo XIX”. En Historia de las artes aplicadas e industriales. Coordinado por Antonio Bonet Correa. Madrid: Ediciones Cátedra, 2008.

Cruz Valdovinos, José Manuel. Los plateros madrileños. Estudio histórico-jurídico de su organización corporativa. Madrid: Edición del Gremio de Joyeros y Plateros de Madrid, 1983.

Cruz Valdovinos, José Manuel. "Plateros aprobados e incorporados al Colegio de San Eloy de Madrid”. En Estudios de Platería. San Eloy 2012. Coordinado por Jesús Rivas Carmona. Murcia: Universidad de Murcia, 2012.

Cruz Valdovinos, José Manuel. "Relación de plateros activos en Madrid en 1861”. En Estudios de Platería. San Eloy 2013. Coordinado por Jesús Rivas Carmona. Murcia: Universidad de Murcia, 2013.

Cuartero Escobés, Susana. "Sigilografía de las logias norteamericanas". Brocar: Cuadernos de investigación histórica 17 (1991): 55-70.

Delaroche Paul, Dupont Henriquel, y Lenormant, Charles. Trésor de Numismatique et de Glyptique. París: Chez Rittner et Goupil Éditeurs, 1840.

Delgado Cruz, Severiano, e Infante Miguel-Motta, Javier. "Nadie preguntaba por ellos. Guerra y represión en Salamanca”. En Testimonio de voces olvidadas. Coordinado por Enrique Berzal de la Rosa. León: Fundación veintisiete de marzo, 2007.

De la Fuente, Vicente. "La lógia "Santa Julia" de Madrid: descripción de la fiesta que hubo en ella el día 28 de Mayo de 1810”. En Historia de las sociedades secretas antiguas y modernas en España y especialmente de la Franc-Masoneria. Editado por Imprenta D.R.P. INFANTE: Madrid, 1874.

Del Corral, Andrés. El misterio de la iniquidad revelado o el triunfo soñado de la impiedad. Valladolid: Hermanos Santander, 1814.

De Mesonero Romanos, Ramón. Memorias de un setentón, natural y vecino de Madrid. Madrid: Renacimiento, 1926.

De Paz-Sánchez, Manuel. "José Aguiar (1895-1976). Entre la luz y las sombras”. Anuario de Estudios Atlánticos 52 (2006): 499-528.

Desantes, Blanca y Frades, María José. Atributos masónicos en el Archivo Histórico Nacional, Sección Guerra Civil. Salamanca: Dirección General de Bellas Artes y Archivos, 1993.

De Viado, Manuel A. Colección de piezas de arquitectura trabajadas en el Taller de Santa Julia. Madrid, 1812.

Echeverría, I. "La Masonería en la cerámica del ParK Güell”. Conbarro: revista internacional de arte 6 (2004): 34-38. 
Ferrer Benimeli, José Antonio, y Bird Polly. Bibliografia de la masonería. Madrid: Fundación Universitaria Española, 2004.

Ferrer Benimeli, José Antonio. "La primera Gran Logia Nacional de España”. En Masonería española contemporánea Vol. 1. 1800-1868. Madrid: Siglo XXI, 1987.

Galán, Ilia, "Introducción". Conde de Aranda. Estudios a la luz de la francmasonería 1 (2006): 13-20.

García Arranz, José Julio. Simbolismo masónico. Historia, fuentes e iconografía. VitoriaGasteiz: Sans Soleil Ediciones, 2017.

García-Diego, José A. Antonio Machado y Juan Gris. Dos artistas masones. Madrid: Castalia, 1990.

Gracia, Josep M. Simbólica arquitectónica. Barcelona: Edición del autor, 2004.

Guibernau, Monserrat. Identidad. Pertenencia, solidaridad y libertad en las sociedades modernas. Madrid: Trotta, 2017.

Hernández, Margarita, Jaramillo Guerreira, Miguel Ángel, y Desantes Fernández, Blanca. "Documentación fotográfica masónica en el Archivo Histórico Nacional: sección guerra civil”. En La masonería española y la crisis colonial del 98. Coordinado por José Antonio Ferrer Benimeli. Zaragoza: CEHME, 1999.

Herrera Chiesanova, Adolfo. Medallas españolas masónicas. Madrid: Edición del autor, 1905.

Hottinger Craig, Sylvia "Las fotografias de mujeres entre las fotografías de origen masónico del archivo general de la Guerra Civil española". En La masonería española: represión y exilios. Coordinado por José Antonio Ferrer Benimeli. Zaragoza: CEHME, 2011.

Júlvez Campos, Manuel, y Pizarro Llorente, Henar. "Masonería bonapartista en Madrid (1812-1829) a través de los papeles inquisitoriales". En Masonería, revolución y reacción. Coordinado por José Antonio Ferrer Benimeli. Alicante: Diputación Provincial de Alicante e Instituto Alicantino de Cultura Juan Gil-Albert, 1990.

Labouret, Marc. Les métaux et la mémoire. La franc-maçonnerie française racontée par ses jetons et médailles. París: Maison Platt Éditeur, 2007.

La masonería española, 1728-1939. Catálogo de exposición. Alicante: Instituto de Cultura "Juan Gil-Albert", Diputación Provincial de Alicante, 1989.

López Tabar, Juan. Los famosos traidores. Los afrancesados durante la crisis del Antiguo Régimen (1808-1833). Madrid: Biblioteca Nueva, 2001.

Martín López, David. “Arte y masonería: consideraciones metodológicas”. REHMLAC 1, no. 2 (diciembre 2009-abril 2010): 17-36. https://revistas.ucr.ac.cr/index.php/rehmlac/article/view/6615/6304

Martín López, David. "Estética masónica, arquitectura y urbanismo. Siglos XVIII-XX". Tesis de doctorado en Historia del Arte y Música, Universidad de Granada, 2010. 
Masonería universal. Una forma de sociabilidad. "Familia gallega" (1814-1936). Catálogo de exposición. A Coruña: Fundación Ara Solis, 1996.

Marvin, T. R. William. The Medals of the Masonic Fraternity. Boston: Edición del autor, 1880.

Menéndez Pelayo, Marcelino. "La heterodoxia entre los afrancesados". En Historia de los heterodoxos españoles, Vol. VII, I. http://www.cervantesvirtual.com/obravisor/historia-de-los-heterodoxos-espanoles/html/

Merzdorf, J. F. L. Theodor. Die Denkmünzen der Freimaurerbrüderchaft. Oldemburgo: Verlag und Druck von Gerhard Stalling, 1851.

Morales Ruiz, Juan José. "Fernando VII y la masonería española". Hispania Nova. Revista de Historia contemporánea 3 (2003): 74-92. http://hispanianova.rediris.es/anteriores3.htm

Muñoz Echeverría, María Elena y Ocaña Vázquez, María Jesús. "Aproximación a la iconografía y simbología masónica". En Masonería, revolución y reacción. Coordinado por José Antonio Ferrer Benimeli. Alicante: Diputación Provincial de Alicante, Instituto Alicantino de Cultura Juan Gil-Albert, 1990.

Muñoz Echeverría, María Elena, y Ocaña Vázquez, María Jesús. "Elementos indígenas y de ultramar en los sellos de las logias de Cuba y Filipinas". En Masonería española y americana. Coordinado por José Antonio Ferrer Benimeli. Zaragoza: CEHME, 1993.

Nogués, Emilio J. M. "Decreto". Boletín de Procedimientos del Soberano Gran Consejo General Ibérico, 3 de abril de 1892.

Ortiz Arellano, Edgar. "Tendencias artísticas del simbolismo francmasónico". Xihmai Revista. 22 (2016): 111-130.

Ortíz Armengol, Pedro. "Viajes y entredichos de Moratín en Francia". Estudios Románticos (1975): 199-266.

Otaola, Javier y Andrés Ortiz-Osés. Masonéria y hermenéutica. Un mundo problemático. Oviedo: EntreAcacias, 2017.

Ramón Solans, Francisco Javier. "El legado historiográfico de Miguel Artola". Rolde. Revista de Cultura Aragonesa (2008): 4-11.

Rodríguez Rubio, Jesús. "Un ejemplo de arte masónico: Nicomedes Gómez (1903-1983)". En Masonería, revolución y reacción. Coordinado por José Antonio Ferrer Benimeli. Alicante: CEHME, 1990.

Royo Martínez, María del Mar. "Guía de descripción, estudio y clasificación de monedas para numismática". Reduca 5, no. 1 (2013): 64-115. http://www.revistareduca.es/index.php/reduca/article/view/1585/1606

Sarriugarte Gómez, Íñigo. "Perspectivas masónicas en la vida y producción artística de Juan Gris”. Cuadernos de arte e iconografia 46 (2014): 523-547. 
Sabater Pie, Juan. "La crisis del 98 en la filatelia masónica". En La masonería española y la crisis colonial del 98. Coordinado por José Antonio Ferrer Benimeli. Zaragoza: CEHME, 1999.

Sabater Pie, Juan. "La masonería en Madrid desde la filatelia (1728-2003)". En La masonería en Madrid y en España del siglo XVIII al XXI. Coordinado por José Antonio Ferrer Benimeli. Zaragoza: CEHME, 2004.

Sánchez Casado, Galo. Los altos grados de la masonería. Madrid: Akal, 2009.

Sánchez Ferré, Pere. La masonería. Símbolos, doctrinas e historia. Santa Cruz de Tenerife: Ediciones Idea, 2015.

Serna Galindo, Ricardo. "La masonería en el séptimo arte. Una aproximación al caso español". REHMLAC+ 8, no. 1 (mayo-noviembre 2016): 71-86. https://doi.org/10.15517/rehmlac.v8i1

Songel, Gabriel. "El patrón de diseño del Santo Cáliz de Valencia". Revista de Bellas Artes 13 (2016): 213-234. 